\title{
ПРАГМАЛИНГВИСТИЧЕСКИЙ АСПЕКТ МАНИПУЛИРОВАНИЯ В ПОЛИТИЧЕСКОМ ДИСКУРСЕ
}

\section{Абдурахманова Диана Залимовна} аспирант ФГАОУ ВО Южный федеральный университет

Аннотация: Функциональная прагмалингвистика рассматривает понятие речевого воздействия. Речевой акт имеет в своём составе локутивный, иллокутивный и перлокутивный компоненты. Последний является одним из определяющих в исследовании политического дискурса. В данной статье рассматривается манипулятивный характер воздействия в политической коммуникации.

Ключевые слова: Прагмалингвистика, речевое воздействие, манипуляция, политический дискурс, речевой акт.

\section{THE PRAGMALINGUISTIC ASPECT OF MANIPULATION IN POLITICAL DISCOURSE}

\section{Abdurakhmanova Diana Zalimovna}

Abstract: Functional pragmalinguistics considers the concept of speech influence. The speech act has locative, illocutive and perlocutive components in its composition. The latter is one of the defining ones in the study of political discourse. This article examines the manipulative nature of influence in political communication.

Key words: Pragmalinguistics, speech influence, manipulation, political discourse, speech act.

Истоки прагмалингвистики восходят к работам Ч. Морриса, в которых прагматика является областью семиотики, изучающей поведение языковых единиц в реальных процессах коммуникации применительно к субъекту и адресату речи [5. с. 43]. Прагмалингвистику можно определить как науку, занимающуюся подбором наиболее приемлемых языковых средств для 
успешного влияния на реципиента, в целях достижения конкретного намеченного результата общения и выполнения индивидуальной коммуникативной задачи. Объектом лингвистической прагматики является отношение (и это ключевое слово) между языковыми единицами и условиями их употребления в определённом коммуникативно-прагматическом пространстве [6. с. 269].

Важно понимать, что на первом месте в исследованиях прагмалингвистики оказывается человек. Любое высказывание соотносится с говорящим и тот, в свою очередь, раскрывает одну из своих социальных функций и психологических особенностей в процессе коммуникации. Безусловно, те же функции имеет и другой участник коммуникации, то есть реципиент. Поэтому необходимо рассматривать и анализировать высказывания согласно параметрам отправителя и получателя сообщения.

Выделяется функциональная прагмалингвистика и скрытая прагмалингвистика. В рамках последней исследуется «интуитивный привычный выбор речевых сигналов актуализации речевого поведения отправителя текста» [7. с. 325$]$.

Понятие речевой деятельности представляет собой одно из ключевых в функциональной прагмалингвистике. Речь есть процесс и одновременно результат говорения, а по своей природе является сугубо индивидуальной. Исследователями прагмалингвистики, среди которых Г.Г. Матвеева, Н.В. Гурова, принято считать, что речь - это инструмент не только для информирования, но и для воздействия на одну из сторон коммуникации. Осуществляемый говорящим речевой акт при этом состоит из локутивного акта (непосредственно акта говорения), иллокутивного акта (произнесения высказывания) и перлокутивного акта (воздействия на слушающего).

Не поддаётся сомнению факт, что понятие дискурс также является важнейшим в области прагмалингвистики. Свои определения этому понятию давали многие учёные, а именно Н.Н. Миронова, О.Л. Михалёва, И.П. Сусов, Ю. Хабермас, Ю.С. Степанов, В.3. Демьянков. Но мы, вслед за Т.А. ван Дейком, склонны определять дискурс как «коммуникативное событие, происходящее между говорящим и слушающим в процессе коммуникативного действия в определенном временном, пространственном и прочем контексте, вбирающем в себя всё многообразие исторической эпохи, индивидуальных и 
социальных особенностей как коммуниканта, так и коммуникативной ситуации, в которой происходит общение» [3. с. 274].

Необходимо отметить, что существуют различные виды дискурса. Мы можем рассматривать дискурс с персональной точки зрения, где говорящий являет свою индивидуальность в многообразии речевых форм. В ином же случае дискурс приобретает другую форму, где говорящий представляет собой часть какого-либо социального института. Так, различают, например, следующие виды дискурса: медицинский, рекламный, спортивный, военный, политический и др. Особое внимание мы уделяем последнему в данной работе.

В политическом дискурсе выделяются свои жанры. Рассматриваются отдельные выступления политиков, программы партий, обсуждения правительства, политические дебаты. Но целью политического дискурса любого жанра является распространение и удержание власти. В этой связи мы можем говорить о высоком манипулятивном потенциале политических высказываний.

Манипуляция понимается как «вид психологического воздействия, искусное исполнение которого ведет к скрытому возбуждению у другого человека намерений, не совпадающих с его, актуально существующими желаниями» [4. с. 59]. Воздействие осуществляется посредством планомерного речевого акта, как нами было отмечено ранее.

Особое место в манипулятивном политическом дискурсе занимают предвыборные дебаты, где обостряется цель «захвата» власти. Так, в предвыборных дебатах 2020 года между Д. Трампом и Дж. Байденом мы находим следующие проявления:

«Because here's the deal, here's the deal. The fact is that everything he's saying so far is simply a lie. I'm not here to call out his lies. Everybody knows he's a liar». (J. Baiden). В данном высказывании Дж. Байден под местоимением he имеет ввиду Д. Трампа. Здесь Байден показательно обвиняет Трампа во лжи (I'm not here to call out his lies), при этом не подкрепляя данное высказывание аргументами. Однако воздействие на аудиторию осуществляется при помощи гиперболы и утверждения (everybody knows he's a liar).

В следующем высказывании Дж. Байден избегает прямого ответа на поставленный вопрос ведущей дебатов:

«Whatever position I take on that, that'll become the issue. The issue is the American people should speak. You should go out and vote. You're voting now. Vote 
and let your Senators know strongly how you feel». При помощи анадиплосиса (...that'll become the issue. The issue is...) президент подчёркивает факт, что в любом случае возникнет проблема. А дальше воздействует на реципиентов лексическими повторами (should speak, should go) и предложением в повелительном наклонении (Vote and let your Senators know...), указывая на то, что решить эту проблему придётся им, а не ему.

Таким образом, прагмалингвистика изучает языковые средства, использующиеся для успешного влияния на реципиента, в целях достижения конкретного намеченного результата общения. При этом важны отношения между этими языковыми единицами и условия коммуникации. В рамках функциональной прагмалингвистики рассматривается политический дискурс, наглядно реализующий свою манипулятивную природу.

\section{Список литературы}

1. Donald Trump \& Joe Biden 1st Presidential Debate Transcript 2020, https://www.rev.com/blog/transcripts/donald-trump-joe-biden-1st-presidential-deba te-transcript-2020

2. Donald Trump \& Joe Biden Final Presidential Debate Transcript 2020, https://www.rev.com/blog/transcripts/donald-trump-joe-biden-final-presidential-deba te-transcript-2020

3. Ван Дейк Т. А. Язык, познание, коммуникация // Прогресс. М., 1989. 310 стр.

4. Кара-Мурза С. Г. Манипуляция сознанием // Эксмо. М., 2008. 862 стр.

5. Моррис Ч. У. Основания теории знаков // Семиотика. М., 1983. С. 42.

6. Серль Дж. Классификация иллокутивных актов // Новое в зарубежной лингвистике. Вып. 17 М., 1986. 424 стр.

7. Сусов И. П. Лингвистика и межкультурная коммуникация: золотая серия // АСТ : Восток-Запад, М., 2007. 384 стр. 